\title{
Relationship between competitiveness and operational and financial performance of firms: An exploratory study on the European brewing industry
}

\author{
Claudio Zanotti*(iD), Fabiola Reyes (D), Brian Fernandez (iD) \\ Universidad Pompeu Fabra - Barcelona School of Management (Spain) \\ *Corresponding author: claudio.zanotti@alum.upf.edu,fabiolalissette.reyes@alum.upf.edu, \\ brianalexander.fernandez@alum.upf.edu
}

Received July, 2017

Accepted January, 2018

\section{Abstract}

Purpose: The purpose of this paper is to provide the underlying constructs that connect the operational and financial performance of firms with the competitive environment surrounding the brewing industry in Europe.

Design/methodology: The selected method of study is exploratory and confirmatory factor analysis, and subsequently applying structural equations modelling. We have sampled 214 brewing companies distributed in over 12 European economies.

Findings: The study provides a comparison between different antecent studies, including contextual contrast in both an industry and a methodologic perspective. The study shoes that the competitive construct of the industry is significantly related with the financial performance of firms, however not necesarilly to the operational results. Additionally, the operational structure of the firm does not necesarilly provide significant relationship to the firms' financial results.

Research limitations/implications: The research is segmented within the European brewing industry, hence we find potentian geographic delimiations in terms of the conclusions of this paper.

Originality/value: Significant relationships between competitive variables and financial performance in the brewing industry remains evasive in research thus far. Additionally, sustained in the potential the brewing industry represents within Europe, it is significant to identify these relationships for readers on both an academic and industrial background.

Keywords: Firm performance, Financial performance, Operational performance, Competitiveness, Brewing industry

Jel Codes: M21

\section{Introduction}

The global beer market has been growing all these years and is also becoming more sophisticated, year to year. It is appropriate and necessary study the brewery industry in all its contexts such as economics, organizational and 
strategic effects. Brewing industry has four essential characteristics which make the study fruitful: (1) has adopted similar technologies globally, (2) offers homogeneous products, (3) dominated by a few large multinational corporations (MNC's), (4) highly internationalized (Gammelgaard \& Dörrenbächer, 2013).

Linked to this, Swinnen (2011) affirms that the production of the beer has been growing for many consecutive years and it won't see to stop. Many brands were reportedly trying to exploit all the possible niche segments by maturing the markets, developing new tastes and changing the lifestyle of consumers, giving to the industry an opportunity of growth.

The global beer market is expected to garner $\$ 688.4$ billion by 2020 , registering a Compound annual growth rate (CAGR) of $6 \%$ during the forecast period 2015-2020. A significant increase in the consumption volume is believed to fuel the market growth even across the developing regions (Bisht, 2015). The 180-country study shows how beer is helping to Europe's economic recovery from the 2008 crisis. The latest statistics confirm that the European brewing sector is now firmly on the path to prosperity. Consumption and production are not just stable, but improving with year-on-year rises in European Union countries from 2014 to 2015 of 1\% in consumption and $1.4 \%$ in production, once again an opportunity for the industry (Brewers of Europe, 2016).

In regard to the European brewing sector, it has been acknowledged as a key actor for job creation and reportedly playing its part in supporting the delivery of the Europe 2020 Growth Strategy (Brewers of Europe, 2016). The EU is the second largest beer producer in the world, after China. There are over 6,500 active breweries, which produced around 383 million hectoliters of beer in 2014 (Kirin Holdings Company, 2014).

The beer industry has made a good and important contribution to the European economy. This sector is generating an estimated 2.3 million jobs: one job in a brewery generates on average a further 17 jobs: two in supply and agriculture, two in retail, and 13 jobs in the bars, pubs, cafés and restaurants of Europe (Brewers of Europe, 2016).

From the Amadeus database (Bureau van Dijk Electronic Publishing, 2017) we can see that in the period between 2015 and 2008, the equity of companies in the industry has had an average yearly growth of 3.39\%, while the overall revenues have had average yearly increase of $4.93 \%$. As we mention before, this industry is facing challenges in all the ways giving many opportunities to the markets.

In a parallel trail of thought, the analysis of the operational performance, competitiveness and financial performance, have been studied for many authors throw all these years (Kroes \& Manikas, 2014). There is precedent for exploratory factorial studies in wine and beer industry, nonetheless with limited scopes or sampling. Thome, Pinho, Fonseca and Soares (2016) performed an exploratory study on beer consumption, yet focusing on the consumers, not the corporate environment, nor their performance variables. Tse, Matthews, Tan, Sato and Pongpanich (2016) reviewed distribution as a component of risk and disruption, however the exploratory sampling was based on an opinion scale, instead of compounded financial or operational indicators. In regards to competitiveness, there are different precedents in the relationship to businesses in the brewing or wine industry. Aquilani, Laureti, Poponi and Secondi (2015) focus on consumer preferences and consumption, Golicic, Davis, Davis-Sramek and McCarthy-Byrne (2014) on the institutions that compose the supply chain and its operations. Nonetheless, these shy from financial implications. Finally, Kim, Yang and Chao (2016) measured the effect of brand equity as a driver in the competitive environment, though with an inverse causal relation, and with a necessarily potent focus on the financials of firms.

In an European perspective, there are instances where there are descriptive studies of market behavior in the beer industry in Europe (Howard, 2014), and a cross-border comparison in market concentration with the United States (Adams, 2011), however, the scope has been more on the policies and the economics (Slade, 2011), rather as the relationships that compose the businesses of the industry as whole.

In connection with the reviews, the beer industry, and the exploratory factor analysis applications, it has been considered relevant to study the European beer industry, hence in that sense the companies that compose its market. This study intends to show data of the most important beers companies in order to show how to 
improve their financial performance and the move towards to opportunities that this sector is facing.In an attempt to fill the void for understanding competitiveness within the brewing industry, this study seeks to connect significant constructs that affect in positive manner the financial performance of firms in the sector, acknowledging its focalized variables. The high market value described, combined with the perceived emptiness in exploratory research, merits the focus of this research in provide a significant construct description in the brewing industry.

This research provides diverse contributions for the field. First, display the interactions between operational impact and financial performance. Second, show the relations amid competitive environments and operational performance. Third, illustrate the association between competitiveness of the industry and financial performance. All of this, in connection to provide a better understanding on the factorial connection between significant constructs within the context of the European brewing. Afterwards, providing results from the analysis, we will present contextual conclusions based on the significant findings.

With this said, the present studies will be structured as follows. Section 2 discusses theoretical uses and antecedents for operational, competitiveness and financials in connection with firms. Section 3 describes the empirical and statistical methodology applied for this study, which is of empirical in nature. Section 4 presents the results derived from the methodology. Section 5 the analysis of the aforementioned in Section 4, and Section 6 shows conclusions from these and this study.

\section{Literature review}

\subsection{Operational impact to the financial performance of firms}

In first regard, we seek to review literature that researches and analyses the impact of operating activities and financial performance. The literature suggests and examines the relationship between cash cycles, firm liquidity, and firm financial performance. We will study several extensions of all these variables. First, cash flows are an essential tool for the company. Businesses faced with the necessity of planning its future, predict the impact of the activities and cash and most necessary to avoid a crisis (Richards \& Laughlin, 1980).

It has been proven by Nerlove (2005) that changes in cash flows will change the firm's performance, he supports his theory by comparing and contrasting firms utilizing a static snapshot measures of cash flow positions and performance from a dynamic viewpoint, therefore the importance of this study.

Theory also suggest that firms can improve liquidity, and hence their competitive positioning by manipulating their cash flows and have as a result better credit, better finance opportunities and the possibility to reduce risks

(Hofmann \& Kotzab (A supply-chain oriented approach of working capital management), 2010). Additional, a firm's ability to generate cash form sales reflects the firm's ability to generate returns effectively from its investments. Firms can manipulate its cash flows in some ways: (i) the time from when goods are sold until the revenue is collected by the firm may change; (ii) the firm's inventory levels may change; and (iii) the time that a firm takes to pay its vendors may change (Hofmann \& Kotzab (A supply-chain oriented approach of working capital management), 2004).

Jalivand and Kim (2013) have argued that cash flows, in an attempt to promote competiveness, are should be applied to the development of profit driven assets, such as research and development. However, Voulgaris and Lemonakis (2014) have argued that this because compromising, since cash flows should be allocated as buffers for potential financial constraints. In a financial administration sense, the operations of a firm can be measure based on the main working capital restrictors: debtors, inventories and creditors (Kroes \& Manikas, 2014; Swaminathan, Smith \& Sadeh, 1998).

Inventories, a familiar component in manufacturing firms, are based on policies that can whether be determinant in a firms cash structure (Miller \& Orr, 1966), and are representative a demand for cash (Baumol, 1952). Debtors, based on how a firm can collect payments in a timely manner, can be significant in that company's liquidity, hence its financials (Gallinger, 1997). 
Based on what has been mentioned previously, the following hypothesis is proposed:

H1: Positives changes in the operational performances will affect positively firm financial performance in the European brewing industry

\subsection{Competitiveness as an impact to the operational and financial performance of firms}

Competitive environments are a source, and a consequence, of firm performance. All three operational components mentioned previously: debtors, inventories and creditors, are related to the competitiveness of the industry, and impacted by the country. Payments and collection are deterministic in the profitability, and have impact in the ability to deal with customers (Paul, Devi \& Teh, 2012). However, in situations of financial and competitive uncertainty, credit and debtor management has significant influence in firm performance (Bastos \& Pindado, 2013). There is also reported evidence that collection policy has significant impact in these credit transactions, but not only customers, but also suppliers (Bastos \& Pindado, 2007), hence contributing to the competitiveness environment. There is evidence that product variety is significant for higher lead times and higher inventories (Salvador, Forza \& Rungtusanatham, 2002), which can be associated with the brewing industry for firms of a wider variety of finished product brands.

Lall (2001) argues that the use of the World Economic Forum, and its competitiveness indicators, is viable in developed economies, since they consider it market friendly and free trade oriented. In the case of the sample population in question for this study, this does not represent such issue.

In a financial context, Turi, Goncalves and Mocan (2014) have argued that in Europe, specifically in the European Union, the regulatory environment in the food industry, which affects the supply chain overall, has a direct effect on not only the operational performance, but also the financial one. This is also extended to quality standards (Clarke, 2010), imposed by the distribution, affecting competitiveness.

In a global context, Sala-I-Martin, Bilbao-Osorio, Blanke, Drzeniek Hanouz and Geiger (2011) mention that a significant factor for a competitive environment is a financial market, which reportedly channels resources in rate of return context, rather than having political or social exposures.

With the premise set by Li, Ragu-Nathan, Ragu-Nathan and Rao (2006), that claims that the supply chain structure of businesses and the industry are to towards competitiveness, which reportedly is linked with higher customer satisfaction (Stanley \& Wisner, 2001), and subsequently to market share (Frohlich \& Westbrook, 2001), and costs efficiencies (Qi, Zhao \& Sheu, 2011). In the same manner, it can be argued that in high levels of competition, lower profit persistency is visualized (Hirsch \& Hartmann, 2014). This however can be inversely argued, if there is significant proportion of market share (Chen \& Lu, 2015), however this is contradicted when an incoming significant actor disrupts the market (Vrontis, Thrassou \& Rossi, 2011).

On an industry perspective, the literature provides background in connection with competitiveness within the beer, the wine and the spirits industries. In a wine contest, Crescimanno and Galati (2014) argue, among other factors, that distribution channels as a mechanism towards competitiveness for Italian wines. However, in regards to market share, firm size, although significant, does not discard small enterprises can create a competitive environment, or participate in one (Sgroi, Testa, Tudisca, Di Trapani \& Dana, 2016). Additionally, there is evidence that the complexity and the sophistication of the competitive environment that allows local market shares to expand internationally (Antohi \& Turtoi, 2014).

In a malt beer perspective, Thome and Soares (International market structure and competitiveness at the malted beer: from 2003 to 2012, 2015) demonstrate that higher concentrated markets, such as Germany, the Netherlands and Belgium, edge in comparison in channelling their sales as exports. In another study, Parsons and De Vanssay (2014) demonstrate the aforementioned that concentrated markets and competition of firms provide rewards in higher relative profits and market share gains. However, as mentioned by Donadini, Fumi, KordialikBogacka, Maggi, Lambri and Sckokai (2016), the European beer industry has seen evidence of flattening sales and room for improvement in profit margins. 
Considering the above details, we propose the following hypothesis as proposed:

H2: Higher competitiveness has a positive impact in the operational performance of firms within the European brewing industry.

H3: Higher competitiveness has a positive impact in the financial performance of firms in the European brewing industry. As a summary, following displays the model, which contains the proposed hypothesis:

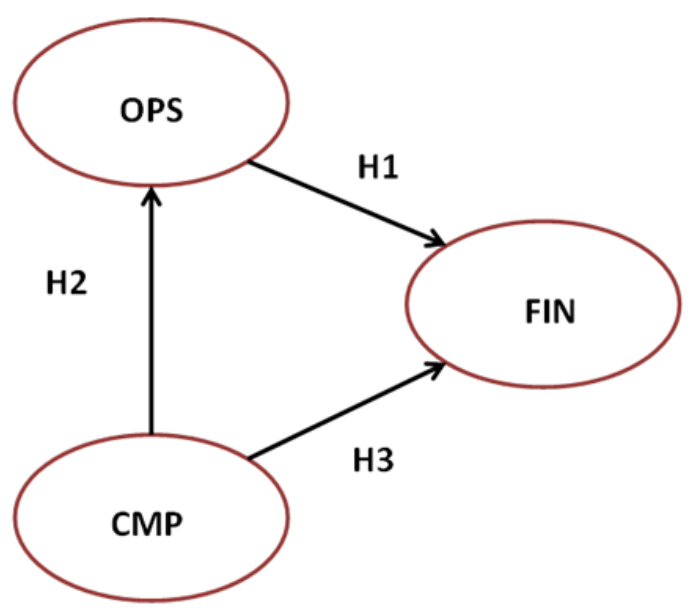

Figure 1. Proposed hypothesis

\section{Methodology}

The following section will be dedicated in describing the sample data, and the measures in its utilization.

\subsection{Sample and data collection}

For the preparation of this study, we used the data from 214 beers companies from the Amadeus repository for firms around Europe, from which we extracted the data for the indicators in the analysis that will be showed. For reasoned exposed previously in this study, our research focuses on companies from brewing sector in specific European countries, and following we present a set of aspects that contextualizes the sample. The firms are the ones within the NACE 1105 Code: Manufacture of Beer.

The Regions and Countries are: Italy, United Kingdom, Albania, Belarus, Bosnia and Herzegovina, Bulgaria, Croatia, Czech Republic, Denmark, Estonia, France, Germany, Hungary, Ireland, Kosovo, Latvia, Lithuania, Macedonia, Moldova, Republic of Montenegro, Norway, Poland, Romania, Serbia, Slovakia, Slovenia, Spain, Sweden, United Kingdom, and Ukraine. For this sample, we have used companies with available financial statements as of the year 2015, spanning from the year 2008.

There are many techniques that analysts and everybody uses to measure the performance of any business enterprise. The most common are the ratios of the industry but which one is the one that we must choose, which one will measure and gave us an idea of how are we doing and if we are doing good. Therefore, check the ratios of the industries and study what the industry is doing is relevant for any study because the economy doesn't affect all in the same way (Amat, Elvira \& Lloret, 2014).

Analysing an industry using ratios as a technique for presenting corporate performance has been widely used. Sometimes ratios present some difficulties, and knowing which ratio to choose as an indicator is very helpful. Altman (1968) affirms that ratios measuring profitability, liquidity, and solvency prevailed as the most significant indicators for comparing and get what that analysts are looking for. This study has analyzed 5 ratios based on 
what we just mention of the industry. Table 2 shows the selected ratios for the brewing industry, in the selected sample.

\begin{tabular}{|l|r|r|}
\hline Total Firms & Companies & Concentration \\
\hline Countries & 24 & $11 \%$ \\
\hline Belgium & 37 & $17 \%$ \\
\hline United Kingdom & 14 & $7 \%$ \\
\hline Ukraine & 12 & $6 \%$ \\
\hline Czech Republic & 11 & $5 \%$ \\
\hline Germany & 11 & $5 \%$ \\
\hline Spain & 10 & $5 \%$ \\
\hline Norway & 10 & $5 \%$ \\
\hline Poland & 8 & $4 \%$ \\
\hline Austria & 5 & $2 \%$ \\
\hline Serbia & 6 & $3 \%$ \\
\hline Italy & 60 & $22 \%$ \\
\hline Others & 26 & $12 \%$ \\
\hline Number Of Employees & 173 & $81 \%$ \\
\hline$>1000$ & 15 & $7 \%$ \\
\hline$<1000$ & \multicolumn{2}{|c|}{} \\
\hline Rest & 7 & $3 \%$ \\
\hline Sales & 87 & $41 \%$ \\
\hline$>1.000 .000$ & 49 & $23 \%$ \\
\hline $0-30.000$ & 62 & $29 \%$ \\
\hline $30.000-90.000$ & 9 & $4 \%$ \\
\hline $90.000-400.000$ & \multicolumn{2}{|c|}{} \\
\hline $400.000-1.000 .000$ & \multicolumn{2}{|c|}{$\mid$} \\
\hline
\end{tabular}

Table 1. Detail of companies in the sample

\begin{tabular}{|l|r|}
\hline Industrial Averages & 2.021 \\
\hline Liquidity & 3.990 \\
\hline Solvency & 2.255 \\
\hline Working Capital Ratio & 0.077 \\
\hline ROA & 0.148 \\
\hline ROE & \\
\hline
\end{tabular}

Table 2. Selected Ratio Averages for Brewing Industry - Europe

\subsection{Measures}

As a result of the analysis of the literature, we propose three dimensions as the subject of this article, in order to compare the aforementioned hypothesis. The first is Financial Performance (FIN), and the variables seek to measure firm financial results, based on a universality perspective, in a perspective of assets and equity. The second dimension is Operational Performance (OPS), in which the objective is to measure the firms operating results, in regard to capital, however separating financial or equity influence. These are extracted from Financial Statements of the sample, however in the format of indicators, since they provide discriminatory power in comparison to monetary mass (Liang, Lu, Tsai \& Shih, 2016). However, one must take into consideration that dimensionality adjustments have to be made to signal adequate positive or negative directional movement (Guyon \& Eliseeff, 2003).

Lastly, the third dimension is Competitiveness (CMP), in which a competitive environment is measured in a national context where the companies of the sample perform business. These variables, selected based on the explanation detailed in Appendix I, are in a Likert scale, with a 0 as lowest and 7 as highest, due to the methodology of their formulation. 


\section{Results}

\subsection{Exploratory Factor Analysis (EFA)}

As followed previously by antecedents in factorial research, utilizing exploratory analysis is of use in order to assess construct validity (Henson \& Roberts, 2006), as a method to evaluate the element-retention criteria of factors (Bagur-Femenías, Perramon \& Amat, 2015). As part of the contrasting analysis, the loads for each factor must be assessed independently (Marsh \& Hocevar, 1985; Wang \& Ahmed, 2004). Afterwards, we must endorse the acceptability of the results, in the past done using the Kaiser-Meyer-Olkin (KMO) index, where an over 0.8 collective result provides acceptability for the overall set and possible sampling when over 0.5 (Beavers, Lounsbury, Richards, Huck, Skolits \& Esquivel, 2013).

The Bartlett Sphericity is later used to evaluate whether the determinant is statistically different from zero, in which if the test is significant, null hypothesis is rejected, which provides evidence of statistical correlation matrix significance (Pett, Lackey \& Sullivan, 2003).

Table 3 shows the details of the statistics obtained in the EFA.

\begin{tabular}{|c|c|c|c|c|}
\hline Dimension & Code & Loads & \multicolumn{2}{|c|}{ Barlett's Test Index and Kaiser-Meyer-Olkin Index } \\
\hline \multirow{3}{*}{ OPS } & OPS1 & 0.830 & KMO Measure of Sampling Adequacy. & 0.500 \\
\hline & \multirow{2}{*}{ OPS2 } & \multirow{2}{*}{0.830} & df & 1.000 \\
\hline & & & Sig. & 0.000 \\
\hline \multirow{4}{*}{ FIN } & FIN1 & 0.802 & KMO Measure of Sampling Adequacy. & 0.546 \\
\hline & FIN2 & 0.920 & \multirow{2}{*}{ df } & \multirow{2}{*}{3.000} \\
\hline & \multirow{2}{*}{ FIN3 } & \multirow{2}{*}{0.723} & & \\
\hline & & & Sig. & 0.000 \\
\hline \multirow{7}{*}{ CMP } & CMP1 & 0.987 & KMO Measure of Sampling Adequacy. & 0.879 \\
\hline & CMP2 & 0.977 & \multirow{4}{*}{ df } & \multirow{4}{*}{21.000} \\
\hline & CMP3 & 0.957 & & \\
\hline & CMP4 & 0.960 & & \\
\hline & CMP5 & 0.922 & & \\
\hline & CMP6 & 0.776 & \multirow{2}{*}{ Sig. } & \multirow{2}{*}{0.000} \\
\hline & CMP7 & 0.919 & & \\
\hline
\end{tabular}

Table 3. Exploratory Factor Analysis (EFA)

\subsection{Confirmatory Factor Analysis(CFA)}

In continuation with the previous section, a confirmatory factor analysis (CFA) was performed to verify factorial structures (Bagur-Femenías et al., 2015), since it is a major advantage in construct validity in comparing alternative models of relationships between these constructs (Strauss \& Smith, 2009). Using Cronbach's Alpha as a reference, which its acceptance stands between 0.5 and 0.7 (Loewenthal, 2001; Carmines \& Zeller, 1979).

Table 4 shows the statistical results for the CFA, in regards to the factor loads. 


\begin{tabular}{|c|c|c|c|c|}
\hline Dimension & Code & Loads & \multicolumn{2}{|c|}{ Composite reliability tests } \\
\hline \multirow{3}{*}{ OPS } & \multirow{2}{*}{ OPS1 } & \multirow{2}{*}{0.830} & Cronbach's alpha & 0.550 \\
\hline & & & AVE & 0.689 \\
\hline & OPS2 & 0.830 & Composite reliability & 0.816 \\
\hline \multirow{3}{*}{ FIN } & FIN1 & 0.802 & Cronbach's alpha & 0.749 \\
\hline & FIN2 & 0.920 & AVE & 0.671 \\
\hline & FIN3 & 0.723 & Composite reliability & 0.858 \\
\hline \multirow{7}{*}{ CMP } & CMP1 & 0.987 & \multirow{2}{*}{ Cronbach's alpha } & \multirow{2}{*}{0.973} \\
\hline & CMP2 & 0.977 & & \\
\hline & CMP3 & 0.957 & \multirow{2}{*}{ AVE } & \multirow{2}{*}{0.866138} \\
\hline & CMP4 & 0.960 & & \\
\hline & CMP5 & 0.922 & \multirow{3}{*}{ Composite reliability } & \multirow{3}{*}{0.97829} \\
\hline & CMP6 & 0.776 & & \\
\hline & CMP7 & 0.919 & & \\
\hline
\end{tabular}

Table 4. Confirmatory Factor Analysis (CFA)

Finally, to conclude the factor analysis, following the references from Fornell and Larcker (1981), using a contrast between the square root of Average Variance Extractions (AVE) for each construct and the correlation between them. In all cases, the square root of AVE was above the values, confirming the model.

\begin{tabular}{|c|r|r|r|}
\cline { 2 - 4 } \multicolumn{1}{c|}{} & \multicolumn{1}{c|}{ OPS } & \multicolumn{1}{c|}{ FIN } & \multicolumn{1}{c|}{ CMP } \\
\hline OPS & $0.830 *$ & & \\
\hline FIN & -0.105 & $0.819^{*}$ & \\
\hline CMP & -0.053 & 0.190 & $0.931 *$ \\
\hline
\end{tabular}

*Square root of AVE

Table 5. Correlation Matrix and discrimination legitimacy

\subsection{Structural equations}

Finally, the proposed model was applied using the limited likelihood method, using the EQS 6.1 (structural equations) software. As suggested in Bagur-Femenías et al. (2015), and ratified by Schermelleh-Engel, Moosbrugger and Muller (2003), if three of the statistics are obtained, within the recommended values validates the models.

\begin{tabular}{|l|r|r|c|}
\hline \multicolumn{1}{|c|}{ Model } & \multicolumn{1}{c|}{ Ideal } & \multicolumn{1}{c|}{ Current } & \multicolumn{1}{c|}{ Source } \\
\hline Bentler-Bonett Normed Fit Index & $>0.8$ & 0.878 & (Hooper, Coughlan \& Mullen, 2007) \\
\hline Comparative Fit Index (Cfi) & $\approx 0.9$ & 0.892 & (Iacobucci, 2010) \\
\hline Bollen's (Ifi) Fit Index & $>0.8$ & 0.893 & (Hu \& Bentler, 1999) \\
\hline Root Mean-Square Residual (Rmr) & $<0.05$ & 0.041 & (Hu Bentler, 1999) \\
\hline Standardized Rmr & $<0.05$ & 0.047 & (Byrne, 1998; Diamantopoulos \& Siguaw, 2000) \\
\hline
\end{tabular}

* Preferred equalled to 0.9 , however not much of significance if it is distanced in sample sizes where $\mathrm{N}>50$

Table 6. EQS Statistics

In this case, following the results concerning the proposed model: 
.045

(1.103)

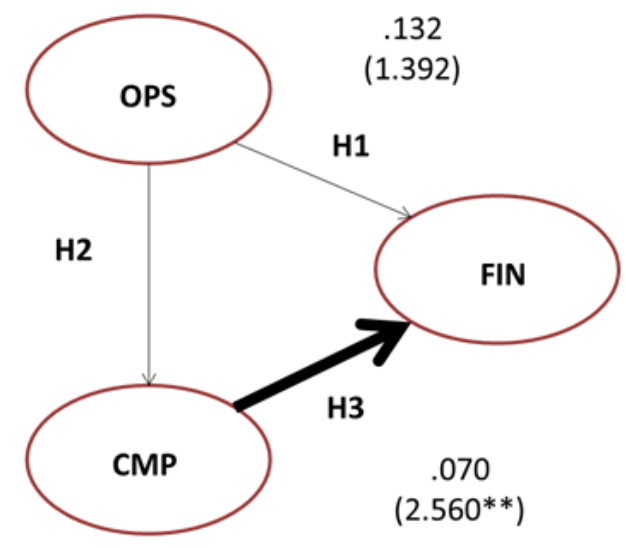

Figure 2. Hypothesis (Maximum likelihood)

\section{Results analysis}

As a result of the application of the structural equation model, we uncover a significant relationship, and relevant findings regarding the non-significant relations between the factors. Firstly, we uncover a lowly significant relationship, nonetheless existent, between Operational Performance and Competitiveness environment. However, as we can visualize, the relationship is inverse as the inquired through the hypothesis. This has been exposed in the past by Vickery, Droge and Markland (1993), which they stress that business and production performance, hence operations, cannot be measured within a universal rule in a context of the industry's competitiveness. Additionally, in industries where market demand is uncertain, operations and business performance will have more impactful influence in the competitiveness of the industry (Gatignon \& Xuereb, 1993). With the information provided initially in this study, demand in the beer industry should not necessarily be considered subjected to significant uncertainty. Finally, one needs to consider the argument that the supply chain structure of the industry could be the construct that determines the competitiveness environment, and not necessarily the businesses that compose it (Fynes, De Burca \& Voss, 2005).

The second relationship that was proven to of lesser statistical significance was between operational and financial performance of the firms in the sample. There is precedent for this absence of synergy (Sueyoshi \& Goto, 2011), performed in an industry in which firms have a significant concentration of fixed assets is significant within the balance sheet (Troy (Almanac of Business and Industrial Financial Ratios), 2008; Troy (Almanac of Business \& Industrial Financial Ratios), 2014), which is comparatively with the brewing industry. Additionally, as an alternative methodology, there is precedent in these conclusions with meta-analysis, where results also show lesser relationships, in which immediate benefits have no significant interaction between financial and operational performance (Leuschner, Rogers \& Charvet, 2013). This matches with the premise that operational integration and increased performance may be bound by different business constraints (Christopher \& Holweg, 2011), which is not essentially driven in the same perspective as the appreciation of financial performance as a measurement of a firms' results (Germain, Davis-Sramek, Lonial \& Raju, 2011).

Finally, we have the interaction between competitiveness to financial performance. Here, the structural equation model shows statistical significance between the factors, hence the hypothesis inquiry can be inferred. Since the competitive variables have a geographic bias, as shown in the measurement section of this study, one can infer that this represents significantly within the analysis. Geographic concentration and growth have been proven drivers of growth in Europe (Martin \& Ottaviano, 1999), and empirical studies prove that this is a driver for the structure of the industry's life cycle (Wang, Madhok \& Xiao Li, 2014), and its competitiveness (Maskell \& Malmberg, 1999).

In the context of financial leverage, which is in one of the significant indicators, there is evidence that competitive environment has non-linear influence within relevant levels (Fosu, 2013). Since reduced levels 
financial leverage have been linked with cost mitigation (Jensen \& Meckling, 1976), and higher competitive environments have an inverse relationship with leverage ratios (Guney, Li \& Fairchild, 2011), it can be inferred that the competitiveness driver of access to financing (Aggarwal \& Goodell, 2014) as a resulting consequence to financial performance. Finally, since customer satisfaction is a sign of competitiveness (Bastos \& Pindado, 2007), there is also proven inverse relationship between leverage and gratification (Malshe \& Agarwal, 2015), hence lover leverage ratios respond to more competitive environments.

Finally, since profitability has been connected to competitive environments (Maletic, Maletic, Al-Najjar \& Gomiscek, 2014), inclusively for small (Bagur-Femenías et al., 2015) and complex businesses (Yusuf, Gunasekaran, Musa, Dauda, El-Berishy \& Cang, 2014), hence applicable for the difference sizes of the firms within brewing industry.

\section{Conclusions}

Although many studies have been performed to analyze either the connections with the operations or the financials of a firm, and the competitiveness of an industry, there was a negated capacity for the factorial and structural understanding of the brewing industry, hence the justification for this exploratory research. In antecedent attempts, external and internal constructs have been designed to explore impacts in financial performance of firms. Madanoglu et al. (2010) performed a study sampling the restaurant industry, however with inconclusive results on significance in relationships, especially in impact on firm cash flows. However, the contrast with this study is also significant on an industry basis, where the asset fixed asset composition in the restaurant industry is meaningfully different from the brewing industry (Troy, 2014).

Chen, Kim and Kim (2005) performed an exploratory study focused on the hospitality industry, but focusing on economic and non-economic discrimination of variables. As a result, the non-economic variables displayed little impact in the performance. In contrast, this study, in respective dimension, has displayed relationship, using noneconomic variables in the process. It must be mentioned that the hospitality industry has a balance sheet differentiation, and their study compared contrasting economic environments, which must be in consideration for variability.

Delen, Kuzey and Uyar (2013) applied exploratory analysis to a single economy, without disregarding industrial segregation. The study provided context for financial performance, and context for local decision making. Nonetheless, without industry classification, as applied in the current study, an overgeneralization is a potential issue.

The factorial relationship in this study confirmed that there is an inconsistent relationship between the competitive environment and the operations in the industry in question, whether the latter is either an active or passive factor towards the first. The research has showed that the small relationship between each other contextualizes the brewing industry in Europe, already exposed to supply chain regulation, and with competitive impact to high fixed asset firms. In that sense, it can be concluded that the apparent lesser connection with the competitive environment assumes that events of disruption in the industry should not have significant impact to the operational performance of firms within it. Additionally, this applies to the structure of balance sheet components, namely debtors, creditors and inventories, which are the operational elements of the firms' working capital. With this evidence, it can be stated that competitive disruption should not be deterministic to neither firm's supply chain nor their significant components of their current assets.

As a result of this study, competitiveness displayed significant relationships with the financial performance of the firm. Although with different academic precedents, financial leveraging showed to have an inverse correlation with a growing competitive environment. In that sense, it can be argued that higher access to financing, and lower costs of it, are significant for the brewing industry. Conversely, it must be mentioned that the geographic distribution of the industry, and the country concentration, shows a regional bias which can either be interpreted as higher barriers for regional entry of foreign competitors, or a direct dependency of local industrial environments. In summary, the study provides conclusive evidence of the financial impact of the competitiveness of the beer industry in Europe, with the caveat of regional and local contextualization. 
Finally, the study ratified previous efforts from other industries, in which the relationship between financial and operational performance cannot be subjected to focalized specifics, which must be taken in consideration on both engaging the industry as business within it, or as a potential customer or vendor through the entire supply chain. It is important to highlight that through the sample of businesses; the competitiveness does not hinder size or company structure, especially when we visualize a concentration $64 \%$ of firms with less than EUR 90m in turnover per year. In that sense, it must be highlight the significance of the applicability to small, medium and large enterprises within the brewing industry, which as mentioned previously will represent a significant source of growth for the region for the near future. The brewing industry has shown competitiveness in potential, which as the evidence shows, it tends forwards to profitability for shareholders and investors in the countries presented.

It must be recommended for future research comparative studies with data sectioned to within each individual economy, in which the sampling or availability of financials is possible. Additionally, the study could be replicated to similar industries such as wines and spirits, which are also subjected to competitiveness, and may face exposure from other international players. Additionally, country or regional segregation must be a consideration, in order to contrast findings in Europe compared to other high or low income economic regions. Also, the segregation could be further focalized, at a country level, with a diversification of sample sizes, and other actors within the beer supply chain. In that sense, further inquiry is required in the separation of industry specific supply chain indicators, for a more focalized analysis be performed in the future.

\section{Declaration of Conflicting Interests}

The authors declared no potential conflicts of interest with respect to the research, authorship, and/or publication of this article.

\section{Funding}

The authors received no financial support for the research, authorship, and/or publication of this article.

\section{References}

Adams, W. J. (2011). Determinants of concentration in beer markets in Germany and the United States: 19502005. In The economics of beer (pp. 227-246). Oxford: Oxford University Press. https://doi.org/10.1093/acprof:oso/9780199693801.003.0013

Aggarwal, R., \& Goodell, J.W. (2014). Cross-national differences in access to finance: Influence of culture and institutional environments. Research in International Business and Finance, 31, 193-211. https://doi.org/10.1016/j.ribaf.2013.09.004

Altman, E.I. (1968). Financial Ratios, Discriminant Analysis and the Prediction of Corporate Bankruptcy. The Journal of Finance, 23(4), 589-609. https://doi.org/10.1111/j.1540-6261.1968.tb00843.x

Amat, O., Elvira, O., \& Lloret, P. (2014). Ratios Sectoriales. Colección MANUALES.

Antohi, L., \& Turtoi, M. (2014). Sales Growth Following the Quality Improvement of the Wine and Wine Products. Journal of Danubian Studies and Research, 4(1), 120-130.

Appuhami, B. (2008). The impact of firms' capital expenditure on working capital management: An empirical study across industries in Thailand. International Management Review, 4(1) 8-21.

Aquilani, B., Laureti, T., Poponi, S., \& Secondi, L. (2015). Beer choice and consumption determinants when craft beers are tasted: An exploratory study of consumer preferences. Food Quality and Preference, 41, 214-224. https://doi.org/10.1016/j.foodqual.2014.12.005

Bagur-Femenías, L., Perramon, J., \& Amat, O. (2015). Impact of quality and environmental investment on business competitiveness and profitability: The case of travel agencies. Total Quality Management \& Business Excellence, 26, 840-853. https://doi.org/10.1080/14783363.2014.895523 
Bastos, R., \& Pindado, J. (2007). An agency model to explain trade credit policy and empirical evidence. Applied Economics, 39, 2631-2642. https://doi.org/10.1080/00036840600722232

Bastos, R., \& Pindado, J. (2013). Trade credit during a financial crisis: A panel data analysis. Journal of Business Research, 66(5), 614-620. https://doi.org/10.1016/j.jbusres.2012.03.015

Baumol, W.J. (1952). The transactions demand for cash: An inventory theoretic approach. The Quarterly Journal of Economics, 66, 545-556. https://doi.org/10.2307/1882104

Beavers, A.S., Lounsbury, J.W., Richards, J.K., Huck, S.W., Skolits, G.J., \& Esquivel, S.L. (2013). Practical considerations for using exploratory factor analysis in educational research. Practical assessment, research \& evaluation, 18(6), 1-13.

Beck, T., Demirgüç-Kunt, A., \& Honohan, P. (2009). Access to Financial Services: Measurement, Impact, and Policies. World Bank Res Obs, 24(1), 119-145. https://doi.org/10.1093/wbro/lkn008

Bisht, P. (2015). Beer Market By Type (Strong Beer, Light Beer), Production (Macro, Micro Brewery), Category (Premium, Super premium, Normal) and Packaging (Canned, Bottled, Draught) - Global Opportunity Analysis and Industry Forecast, 2014 - 2020. Allied Market Research.

Bontis, N., Keow, W.C., \& Richardson, S. (2000). Intellectual capital and business performance in Malaysian industries. Journal of Intellectual Capital, 1(1), 85-100. https://doi.org/10.1108/14691930010324188

Brewers of Europe (2016). The Contribution made by Beer to the European Economy. Europe Economics.

Bureau van Dijk Electronic Publishing (2017). Company information across Europe. Retrieved 2017, from Bureau van Dijk Electronic Publishing: https://www.bvdinfo.com/en-us/our-products/company-information/internationalproducts/amadeus

Byrne, B. (1998). Structural Equation Modeling with LISREL, PRELIS, and SIMPLIS: Basic Concepts, Applications, and Programming. New York: Psychology Press.

Carmines, E.G., \& Zeller, R.A. (1979). Quantitative Applications in the Social Sciences: Reliability and validity assessment. Thousand Oaks, CA: SAGE Publications Ltd. https://doi.org/10.4135/9781412985642

Chen, M.H., Kim, W.G., \& Kim, H.J. (2005). The impact of macroeconomic and non-macroeconomic forces on hotel stock returns. International Journal of Hospitality Management, 24(2), 243-258.

https://doi.org/10.1016/j.ijhm.2004.06.008

Chen, S.-Y., \& Lu, C.-C. (2015). Assessing the competitiveness of insurance corporations using fuzzy correlation analysis and improved fuzzy modified TOPSIS. Expert Systems, 32(3), 392-404.

https://doi.org/10.1111/exsy.12099

Christopher, M., \& Holweg, M. (2011). Supply chain 2.0: Managing supply chains in the era of turbulence. The International Journal of Physical Distribution and Logistics Management, 41(1), 63-82. https://doi.org/10.1108/09600031111101439

Clague, C., Keefer, P., Knack, S., \& Olson, M. (1999). Contract-Intensive Money: Contract Enforcement, Property Rights, and Economic Performance. Journal of Economic Growth, 4(2), 185-211.

https://doi.org/10.1023/A:1009854405184

Clarke, R. (2010). Private Food Safety Standards: Their Role in Food Safety Regulation and their Impact. Session of the Codex Alimentarius Comission, 33.

Crescimanno, M., \& Galati, A. (2014). Competitiveness of Italian Wines In The International Market. Bulgarian Journal of Agricultural Science, 20(1), 12-22.

Delen, D., Kuzey, C., \& Uyar, A. (2013). Measuring firm performance using financial ratios: A decision tree approach. Expert Systems with Applications, 40(10), 3970-3983. https://doi.org/10.1016/j.eswa.2013.01.012

Diamantopoulos, A., \& Siguaw, J. (2000). Introducing Statistical Methods: Introducing LISREL. London: SAGE Publications Ltd. https://doi.org/10.4135/9781849209359 
Donadini, G., Fumi, M., Kordialik-Bogacka, E., Maggi, L., Lambri, M., \& Sckokai, P. (2016). Consumer interest in specialty beers in three European markets. Food Research International, 85, 301-314. https://doi.org/10.1016/j.foodres.2016.04.029

Fornell, C., \& Larcker, D.F. (1981). Evaluating structural equation models with unobservable variables and measurement error. Journal of Marketing Research, 18(1), 39-50. https://doi.org/10.2307/3151312

Fosu, S. (2013). Capital structure, product market competition and firm performance: Evidence from South Africa. The Quarterly Review of Economics and Finance, 53(2), 140-151. https://doi.org/10.1016/j.qref.2013.02.004

Frohlich, M., \& Westbrook, R. (2001). Arcs of integration: an international study of supply chain strategies. Journal of Operations Management, 19, 185-200. https://doi.org/10.1016/S0272-6963(00)00055-3

Fynes, B., \& Voss, C. (2002). The moderating effect of buyer-supplier relationships on quality practices and performance. International Journal of Operations \& Production Management, 22(6), 589-613. https://doi.org/10.1108/01443570210427640

Fynes, B., De Burca, S., \& Voss, C. (2005). Supply chain relationship quality, the competitive environment and performance. International Journal of Production Research, 43(16), 3303-3320. https://doi.org/10.1080/00207540500095894

Gallinger, G. (1997). The current and quick ratios: Do they stand up to scrutiny?. Business Credit, 99(5), 22-25.

Gammelgaard, J., \& Dörrenbächer, C. (2013). The Global Brewery Industry. USA: Edward Elgar Publishing Limited. https://doi.org/10.4337/9781781006351

Gatignon, H., \& Xuereb, J.-M. (1993). Strategic Orientation of the Firm and New Product Performance. Journal of Marketing Research, 34(1), 77-90. https://doi.org/10.2307/3152066

Germain, R., Davis-Sramek, B., Lonial, S.C., \& Raju, P.S. (2011). The impact of relational supplier exchange on financial performance: A study of the hospital sector. Journal of Business Logistics, 32(3), $240-253$. https://doi.org/10.1111/j.2158-1592.2011.01020.x

Golicic, S.L., Davis, D.F., Davis-Sramek, B., \& McCarthy-Byrne, T.M. (2014). Institutional Pressures and Relationships in the Wine Supply Chain (8th Edition)(pp. 1-16). Academy of Wine and Business Research.

Gunasekaran, A., Patel, C., \& Mc Gaughey, R.E. (2004). A framework for supply chain performance measurement. International Journal of Production Economics, 87(3), 333-347.

https://doi.org/10.1016/j.ijpe.2003.08.003

Guney, Y., Li, L., \& Fairchild, R. (2011). The relationship between product market competition and capital structure in Chinese listed firms. International Review of Financial Analysis, 20(1), 41-51.

https://doi.org/10.1016/j.irfa.2010.10.003

Guyon, I., \& Eliseeff, A. (2003). An Introduction to Variable and Feature Selection. Journal of Machine Learning Research, 3, 1157-1182.

Hancock, J.I., Allen, D.G., Bosco, F.A., McDaniel, K.R., \& Pierce, C.A. (2011). Meta-Analytic Review of Employee Turnover as a Predictor of Firm Performance. Journal of Management, 39(3), $573-603$. https://doi.org/10.1177/0149206311424943

Henson, R.K., \& Roberts, J.K. (2006). Use of Exploratory Factor Analysis in Published Research: Common Errors and Some Comment on Improved Practice. Educational and Psychological Measurement (EPM), 66(3), 393-416. https://doi.org/10.1177/0013164405282485

Hill, M.D., Kelly, G., \& Highfield, M.J. (2010). Net Operating Working Capital Behavior: A First Look. Financial Management, 39, 783-805. https://doi.org/10.1111/j.1755-053X.2010.01092.x

Hirsch, S., \& Hartmann, M. (2014). Persistence of firm-level profitability in the European dairy processing industry. Agricultural Economics - The Journal of the International Association of Agricultural Economics, 45(S1), 53-63. https://doi.org/10.1111/agec.12129 
Hofmann, E., \& Kotzab, H. (2004). A supply-chain oriented approach of working capital management. Int. J. Prod. Econ, 87(3), 333-347.

Hofmann, E., \& Kotzab, H. (2010). A supply-chain oriented approach of working capital management. Journal of Business Logistics, 31, 305-330. https://doi.org/10.1002/j.2158-1592.2010.tb00154.x

Hooper, D., Coughlan, J., \& Mullen, M. (2007). Structural Equation Modelling: Guidelines for Determining Model Fit. Electronic Journal on Business Research Methods, 6(1), 53-60.

Hovakimian, A., Opler, T., \& Titman, S. (2001). The Debt-Equity Choice. Journal of Financial and Quantitative Analysis, 1-24. https://doi.org/10.2307/2676195

Howard, P.H. (2014). Too Big to Ale? Globalization and Consolidation in the Beer Industry. In M. Patterson, \& N. Hoalst-Pullen (Eds.), The Geography of Beer (pp. 155-165). Dordrecht: Springer Science + Business Media Dordrecht 2014. https://doi.org/10.1007/978-94-007-7787-3_14

Hu, L.-T., \& Bentler, P.M. (1999). Cutoff criteria for fit indexes in covariance structure analysis: Conventional criteria versus new alternatives. Structural Equation Modeling: A Multidisciplinary Journal, 6(1), 1-55. https://doi.org/10.1080/10705519909540118

Iacobucci, D. (2010). Structural equations modeling: Fit Indices, sample size, and advanced topics. Journal of Consumer Psycology, 20, 90-98. https://doi.org/10.1016/j.jcps.2009.09.003

Jalivand, A., \& Kim, S.M. (2013). Matching slack resources and investment strategies to achieve long-term performance: New perspectives on corporate adaptability. The Journal of Economic Asymmetries, 10(1), 38-52. https://doi.org/10.1016/j.jeca.2013.10.001

Jensen, M., \& Meckling, W. (1976). Theory of the firm: Managerial behaviour, agency costs and ownership structure. Journal of Financial Economics, 3, 305-360. https://doi.org/10.1016/0304-405X(76)90026-X

Kaufmanna, L., \& Carter, C.R. (2006). International supply relationships and non-financial performance-A comparison of U.S. and German practices. Journal of Operations Management, 24(5), 653-675. https://doi.org/10.1016/j.jom.2005.07.001

Kim, R., Yang, H., \& Chao, Y. (2016). Effect of brand equity\& country origin on Korean consumers' choice for beer brands. The Business and Management Review, 7(3), 398-403.

Kirin Holdings Company (2014, August 8). Kirin Beer University Report: Global Beer Production by Country in 2013. Retrieved March 05, 2017, from Kirin Holdings Company, Limited: http://www.kirinholdings.co.jp/english/news/2014/0808 01.html

Kroes, J.R., \& Manikas, A.S. (2014). Cash flow management and manufacturing firm financial performance: A longitudinal perspective. Int. J. Production Economics, 148, 37-50. https://doi.org/10.1016/j.ijpe.2013.11.008

Lall, S. (2001). Competitiveness Indices and Developing Countries: An Economic Evaluation of the Global Competitiveness Report. World Development, 29(9), 1501-1525. https://doi.org/10.1016/S0305-750X(01)00051-1

Leuschner, R., Rogers, D.S., \& Charvet, F.F. (2013). A Meta-Analysis of Supply Chain Integration and Firm Performance. Journal of Supply Chain Management, 49(2), 34-57. https://doi.org/10.1111/jscm.12013

Li, S., Ragu-Nathan, B., Ragu-Nathan, T., \& Rao, S. (2006). The impact of supply chain management practices on competitive advantage and organizational performance. Omega - The International Journal of Management Science, 34, 107-124. https://doi.org/10.1016/j.omega.2004.08.002

Liang, D., Lu, C.-C., Tsai, C.-F., \& Shih, G.-A. (2016). Financial ratios and corporate governance indicators in bankruptcy prediction: A comprehensive study. European Journal of Operational Research, 252, 561-572. https://doi.org/10.1016/j.ejor.2016.01.012

Loewenthal, K.M. (2001). An introduction to psychological tests and scales. Philadelphia, PA: Psychology Press.

Madanoglu, M., Olsen, M.D., \& Kwansa, F. (2010). Restaurant Industry Risk Dimensions and their Influence on Operating Cash Flows. 2010 ICHRIE Conference. 
Maletic, D., Maletic, M., Al-Najjar, B., \& Gomiscek, B. (2014). The role of maintenance in improving company's competitiveness and profitability: A case study in a textile company. Journal of Manufacturing Technology Management, 25(4), 441-456. https://doi.org/10.1108/JMTM-04-2013-0033

Malshe, A., \& Agarwal, M.K. (2015). From Finance to Marketing: The Impact of Financial Leverage on Customer Satisfaction. Journal of Marketing, 79(5), 21-38. https://doi.org/10.1509/jm.13.0312

Marsh, H.W., \& Hocevar, D. (1985). Application of confirmatory factor analysis to the study of self-concept: First- and higher order factor models and their invariance across groups. Psychological Bulletin, 97(3), 562-582. https://doi.org/10.1037/0033-2909.97.3.562

Martin, P., \& Ottaviano, G.I. (1999). Growing locations: Industry location in a model of endogenous growth. European Economic Review, 43(2), 281-302. https:/ / doi.org/10.1016/S0014-2921(98)00031-2

Maskell, P., \& Malmberg, A. (1999). The Competitiveness of Firms and Regions - Ubiquitification' and the Importance of Localized Learning. European Urban and Regional Studies, 6(1), 9-25. https://doi.org/10.1177/096977649900600102

Miller, M.H., \& Orr, D. (1966). A Model of the Demand for Money by Firms. Quarterly Journal of Economics, 80(3), 413-435. https://doi.org/10.2307/1880728

Nerlove, M. (2005). Essays in Panel Data Econometrics. Cambridge: Cambridge University Press.

Ongore, V.O., \& Kusa, G.B. (2013). Determinants of Financial Performance of Commercial Banks in Kenya. International Journal of Economics and Financial Issues, 3(1), 237-252.

Parsons, C.R., \& De Vanssay, X. (2014). Detecting Market Competition in the Japanese Beer Industry. Journal of Industry, Competition and Trade, 14, 123-143. https://doi.org/10.1007/s10842-013-0166-9

Paul, S.Y., Devi, S.S., \& Teh, C.G. (2012). Impact of late payment on Firms' profitability: Empirical evidence from Malaysia. Pacific-Basin Finance Journal, 20(5), 777-792. https://doi.org/10.1016/j.pacfin.2012.03.004

Pett, M.A., Lackey, N.R., \& Sullivan, J.J. (2003). Making Sense of Factor Analysis - The Use of Factor Analysis for Instrument Development in Health Care Research. Thousand Oaks, CA: Sage Publications. https://doi.org/10.4135/9781412984898

Qi, Y., Zhao, X., \& Sheu, C. (2011). The impact of competitive strategy and supply chain strategy on business performance: The role of environmental uncertainty. Decision Sciences - A Journal of the Decision Sciences Institute, 42(2), 371-389. https://doi.org/10.1111/j.1540-5915.2011.00315.x

Richards, V.D., \& Laughlin, E.J. (1980). A Cash Conversion Cycle Approach to Liquidity Analysis. Financial Management, 9(1), 32-38. https://doi.org/10.2307/3665310

Sala-I-Martin, X., Bilbao-Osorio, B., Blanke, J., Drzeniek Hanouz, M., \& Geiger, T. (2011). The Global Competitiveness Index 2011-2012: Setting the Foundations for Strong Productivity. In The Global Competitiveness Report 2011-2012. Geneva: World Economic Forum.

Salvador, F., Forza, C., \& Rungtusanatham, M. (2002). Modularity, product variety, production volume, and component sourcing: theorizing beyond generic prescriptions. Journal of Operational Management, 20(5), 549-575. https://doi.org/10.1016/S0272-6963(02)00027-X

Schermelleh-Engel, K., Moosbrugger, H., \& Muller, H. (2003). Evaluating the fit of structural equation models: Tests of significance and descriptive goodness-of-fit measures. Methods of psychological research online, 8(2), 23-74.

Sgroi, F., Testa, R., Tudisca, S., Di Trapani, A.M., \& Dana, L.-P. (2016). Growth and sustainability of agricultural systems: The case of Sicilian wine-growing farms. International Journal of Entrepreneurship and Small Business (IJESB), 29(1), 103-111. https://doi.org/10.1504/IJESB.2016.078047 
Slade, M.E. (2011). Competition policy towards brewing: rational response to market power or unwarranted interference in efficient markets?. In The economics of beer (pp. 173-195). Oxford: Oxford University Press. https://doi.org/10.1093/acprof:oso/9780199693801.003.0010

Stanley, L., \& Wisner, J. (2001). Service quality along the supply chain: Implications for purchasing. Journal of Operations Management, 19, 287-306. https://doi.org/10.1016/S0272-6963(00)00052-8

Strauss, M.E., \& Smith, G.T. (2009). Construct validity: Advances in theory and methodology. Annual Review of Clinical Psychology, 5, 1-25. https://doi.org/10.1146/annurev.clinpsy.032408.153639

Sueyoshi, T., \& Goto, M. (2011). Operational synergy in the US electric utility industry under an influence of deregulation policy: A linkage to financial performance and corporate value. Energy Policy, 39(2), 699-713. https://doi.org/10.1016/j.enpol.2010.10.043

Swaminathan, J.M., Smith, S.F., \& Sadeh, N.M. (1998). Modeling Supply Chain Dynamics: A Multiagent Approach. Decision Sciences, 29(3), 607-632. https://doi.org/10.1111/j.1540-5915.1998.tb01356.x

Swinnen, J.F. (2011). The Economics of Beer. NYC, USA: Oxford University Press. https://doi.org/10.1093/acprof:oso/9780199693801.001.0001

Thome, K.M., \& Soares, A.D. (2015). International market structure and competitiveness at the malted beer: From 2003 to 2012. Agric. Econ.-Cžech, 61, 166-178. https://doi.org/10.17221/189/2014-AGRICECON

Thome, K.M., Pinho, G.D., Fonseca, D.P., \& Soares, A.B. (2016). Consumers' luxury value perception in the Brazilian premium beer market. International Journal of Wine Business Research, 28(4), 369-386. https://doi.org/10.1108/IJWBR-09-2015-0043

Troy, L. (2008). Almanac of Business and Industrial Financial Ratios (39 ed.). Chicago, IL: CCH Inc.

Troy, L. (2014). Almanac of Business \& Industrial Financial Ratios (45 ed.). Chicago, IL: CCH Inc.

Tse, Y.K., Matthews, R.L., Tan, K.H., Sato, Y., \& Pongpanich, C. (2016). Unlocking supply chain disruption risk within the Thai beverage industry. Industrial Management \& Data Systems, 116(1), 21-42. https://doi.org/10.1108/IMDS-03-2015-0108

Turi, A., Goncalves, G., \& Mocan, M. (2014). Challenges and competitiveness indicators for the sustainable development of the supply chain in food industry. Procedia - Social and Behavioral Sciences, 124, 133-141. https://doi.org/10.1016/j.sbspro.2014.02.469

Vickery, S.K., Droge, C., \& Markland, R.E. (1993). Production Competence and Business Strategy: Do They Affect Business Performance?. Decision Sciences, 24(2), 435-456.https://doi.org/10.1111/j.15405915.1993.tb00482.x

Voulgaris, F., \& Lemonakis, C. (2014). Competitiveness and profitability: The case of chemicals, pharmaceuticals and plastics. The Journal of Economic Asymmetries, 11, 46-57. https://doi.org/10.1016/j.jeca.2014.04.003

Vrontis, D., Thrassou, A., \& Rossi, M. (2011). Italian wine firms: strategic branding and financial performance. International Journal of Organizational Analysis, 19(4), 288-304. https://doi.org/10.1108/19348831111173423

Wang, C.L., \& Ahmed, P.K. (2004). The development and validation of the organisational innovativeness construct using confirmatory factor analysis. European Journal of Innovation Management, 7(4), 303-313. https://doi.org/10.1108/14601060410565056

Wang, L., Madhok, A., \& Xiao Li, S. (2014). Agglomeration and clustering over the industry life cycle: Toward a dynamic model of geographic concentration. Strategic Management Journal, 35(7), 995-1012. https://doi.org/10.1002/smj.2141

Yusuf, Y.Y., Gunasekaran, A., Musa, A., Dauda, M., El-Berishy, N.M., \& Cang, S. (2014). A relational study of supply chain agility, competitiveness and business performance in the oil and gas industry. International Journal of Production Economics, 147(Part B), 531-543. https://doi.org/10.1016/j.ijpe.2012.10.009 


\section{Appendix}

\begin{tabular}{|c|c|c|c|}
\hline Code & Group & Variable/Indicator & Reference \\
\hline IDSO & OPS & Inverse Days Sales Outstanding & $\begin{array}{l}\text { Madanoglu, Olsen \& Kwansa, } \\
\text { 2010) }\end{array}$ \\
\hline IDIO & OPS & Inverse Days Inventory Outstanding & (Madanoglu et al., 2010) \\
\hline $\mathrm{DPO}$ & OPS & $\begin{array}{l}\text { Days Payables Outstanding } \\
(1 / \mathrm{DPO})\end{array}$ & (Madanoglu et al., 2010) \\
\hline CCC & OPS & Cash Conversion Cycle & (Madanoglu et al., 2010) \\
\hline $\mathrm{OCC}$ & OPS & Operating Cash Cycle & (Madanoglu et al., 2010) \\
\hline CWCD & OPS & $\begin{array}{c}\text { Commercial Working Capital Deficit } \\
\text { as a percentage of WC }\end{array}$ & (Appuhami, 2008) \\
\hline Grow & OPS & Sales Growth Year on Year & (Kroes \& Manikas, 2014) \\
\hline D_WC & OPS & Debtor WC Deficit & (Appuhami, 2008) \\
\hline S_WC & OPS & Stocks WC Deficit & (Appuhami, 2008) \\
\hline C_WC & OPS & Creditor WC Deficit & (Appuhami, 2008) \\
\hline ROE & FIN & Return on Equity & (Kroes \& Manikas, 2014) \\
\hline $\mathrm{ROA}$ & FIN & Return on Assets & (Kroes \& Manikas, 2014) \\
\hline TOBINS_Q & FIN & Q Ratio (Tobins Q) & (Kroes \& Manikas, 2014) \\
\hline C_Debt & FIN & Cost of Debt & (Kroes \& Manikas, 2014) \\
\hline WC_Ratio & FIN & Working Capital Ratio & (Hill, Kelly \& Highfield, 2010) \\
\hline Debt_Equity_Ratio & FIN & Debt to Equity Ratio & (Hovakimian, Opler \& Titman, \\
\hline Net_Profit & FIN & Net Profit Ratio & (Kroes \& Manikas, 2014) \\
\hline As_Turn & FIN & Asset Turnover & (Kroes \& Manikas, 2014) \\
\hline Fin_Lev & FIN & Financial Leverage & (Kroes \& Manikas, 2014) \\
\hline P_E & CMP & Profit per Employee & $\begin{array}{l}\text { (Hancock, Allen, Bosco, McDaniel } \\
\text { \& Pierce, 2011) }\end{array}$ \\
\hline E_Share & CMP & Equity Share & (Ongore \& Kusa, 2013) \\
\hline M_Share & CMP & Market Share & (Ongore \& Kusa, 2013) \\
\hline Int_Prop & CMP & Intellectual Property Protection & (Bontis, Keow \& Richardson, 2000) \\
\hline Prop_Rig & CMP & Property Rights & $\begin{array}{c}\text { (Clague, Keefer, Knack \& Olson, } \\
1999)\end{array}$ \\
\hline Aff_Fin & CMP & Affordability of financial services & $\begin{array}{c}\text { (Beck, Demirgüç-Kunt \& } \\
\text { Honohan, 2009) }\end{array}$ \\
\hline Buy_Sof & CMP & Buyer Sophistication & (Fynes \& Voss, 2002) \\
\hline Cnt_Int & CMP & $\begin{array}{l}\text { Control of International } \\
\text { Distribution }\end{array}$ & (Kaufmanna \& Carter, 2006) \\
\hline Ease_Fin & CMP & Ease of access to loans & (Beck et al., 2009) \\
\hline VCh_B & CMP & Value Chain Breadth & $\begin{array}{l}\text { (Gunasekaran, Patel \& Mc Gaughey, } \\
\text { 2004) }\end{array}$ \\
\hline
\end{tabular}

Table A1. Variables

Intangible Capital, 2018 (www.intangiblecapital.org)

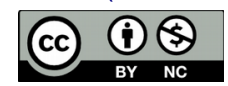

Article's contents are provided on an Attribution-Non Commercial 4.0 Creative commons International License. Readers are allowed to copy, distribute and communicate article's contents, provided the author's and Intangible Capital's names are included. It must not be used for commercial purposes. To see the complete license contents, please visit https://creativecommons.org/licenses/by-nc/4.0/. 